\title{
A triadic construct in Jubilees 30
}

Author:

Pieter M. Venter

\section{Affiliation: \\ ${ }^{1}$ Department of Old \\ Testament Studies, \\ University of Pretoria, \\ South Africa}

\section{Correspondence to:}

Pieter Venter

email:

pm.venter@up.ac.za

\section{Postal address:}

PO Box 914-1530, Wingate

Park 0153, South Africa

\section{Keywords:}

Book of Jubilees; Dinah's

ravishment; Jewish

identity; Old Testament

ethics; Triadic constructs of

interrelated concepts

\section{Dates:}

Received: 25 Feb. 2009

Accepted: 11 June 2009

Published: 23 July 2010

How to cite this article Venter, P.M., 2010, 'A triadic construct in Jubilees 30 ', HTS Teologiese Studies/ Theological Studies 66(1), Art. \#801, 8 pages. DOI: 10.4102/ hts.v66i1.801

\section{This article is available} at: http://www.hts.org.za
(C) 2010. The Authors. Licensee: OpenJournals Publishing. This work is licensed under the Creative Commons Attribution License.

\section{ABSTRACT}

Publications on Old Testament ethics often use triadic constructs to explain the moral impact of Biblical passages. In Genesis 11:27-50:26, Ezra 9:6-15, Nehemiah 7:72b-10:40, Damascus Document (CD) V:1, 2-6 and Jubilees 8-9 and 23, constructs of three interrelated concepts are used, all related to the issue of marriage. This paper investigates the story of Dinah's ravishment in the book of Jubilees 30:1-25 and compares it to the original rendition in Genesis 33:18-34:31. The conclusion is drawn that both renditions use a construct of three interrelated concepts. Genesis uses a triad of progeny, marriage and land. The book of Jubilees uses an interrelated construction of Law, identity and marriage. In Jubilees the focus is shifted from the shame of Dinah's rape to the shame of intermarriage between different groups in Jubilees. Here a cultic-oriented person links the laws revealed to Moses with his particular view on intermarriage and purity/impurity. His purpose is to propagate a new purified identity for the Jews of his day.

\section{INTRODUCTION}

Since Emil Brunner, Old Testament morality paradigms have been presented as multidimensional constructs. Following this, Brunner Janzen (1994:2) aimed to grasp 'the Old Testament's ethical message in a comprehensive way', by proposing a 'familial paradigm' as representing Old Testament ethics. This paradigm is sustained by priestly, sapiential, royal and prophetic paradigms as distinctive modes of seeking the same God-willed life (cf. Janzen 1994:178). In all of these models, 'the terms life, land and hospitality are to be understood as focal terms or shorthand for perspectives contained in stories and other texts' (cf. Janzen 1994:178). His 'familial paradigm', therefore, operates with a triad of three concepts: life, land and hospitality.

Similarly, in both of his publications on Biblical ethics, Wright $(1983,2004)$ used a triad of 'God', 'Israel' and 'the land' to understand the ethical thrust of the Old Testament. According to his view, the Old Testament's ethical teachings should be examined in terms of theological (God), social (Israel) and economic (the land) cornerstones. These are the 'three pillars of Israel's worldview, the primary factors of their theology and ethics' (Wright 2004:19). For example, when Wright (2004:327-362) deals with 'Culture and Family' he does so in terms of these three interrelated concepts. In this case he uses the terms God, the extended family and the land. Although exchanging terms, he still uses a triad of concepts to formulate what the ethics of the Old Testament are.

Likewise, in her study of Biblical morality, Mary Mills (2001) aims at formulating a hermeneutic for reading Old Testament narratives, with an eye towards their moral perspectives. She uses a triangular structure of 'cosmos', 'community' and 'person' to indicate a subtle interweaving of meaning in these texts. In her view, the divine ordering of the world has ramifications right down to the level of an individual human being's experience of daily affairs such as health and prosperity (cf. Mills 2001:20).

I find the use of a multidimensional approach using interrelated concepts very attractive for studying the ethical message of the Bible and related literature. However, I prefer Mills' constructs to those of Janzen and Wright. She concentrates on identity rather than mere ethics. According to Mills, the purpose of stories and legal statements in the Bible is 'not ethical behaviour per se, but the place of such elements in a society's self-identity' (Mills 2001:3). To understand the concept of biblical morality, the whole presentation of the moral material should be taken into account, 'not merely obviously legalistic snippets abstracted from their biblical moorings' (Mills 2001:21). In other words, the actual texts come first in ethical study. Each book and each section of a book must be taken on its own terms and according to its own language code (cf. Mills 2001:4). We are not to use any external scheme, but only that one presented by the text itself. The theological message of the text and its ethical implications are to be deduced as far as possible from the text itself. Furthermore, I am of the persuasion that not only the literary genre of a text, but also its literary context as well as its socio-historic background should be studied to fathom the theology presented in that text and its consequential moral pattern.

While doing research on texts in Genesis, ${ }^{1}$ Ezra-Nehemiah, ${ }^{2}$ the Damascus Document ${ }^{3}(\mathrm{CD})$ and Jubilees, ${ }^{4}$ I came to the conclusion that constructs of three interrelated concepts are also used in these texts. In this paper, I focus on the narrative of Dinah's rape in Jubilees 30:1-25. The question is whether the author of Jubilees also used a three-part construct in rewriting the original story presented in Genesis 33:1834:31. If so, are there any differences between the constructs used in both texts? Can the results of this investigation help us to understand more clearly Jubilees' specific ethical ideas on intermarriage for the

1.Venter 2007b:1213-1237.

2.Venter 1995:720-731, 2005:545-563.

3.Venter 2003b:598-622.

4.Venter 2003a:957-989, 2007a:463-480, 2008:631-650. 
Jews of his day? For the purpose of the study, I will first recap my previous research to show the use of triadic constructs in the cases indicated above. This, in turn, will serve as the basis for my investigation into Jubilees 30 .

\section{A TRIAD IN GENESIS}

Steinberg's (1993) theory is that a triad of concepts (heirship, marriage and land) is used in the patriarchal cycles of Genesis. This integrated construct is used in Genesis to indicate the identity of the post-exilic community in Yehud. These concepts are used as interrelated metaphors to illustrate what a relationship with the Lord means for his people and the type of identity it entails for them. The real identity of Israel is thus expressed in terms of a triad of interrelated concepts in order to define the relationship with the Lord and to indicate the expected socio-political relationships to be found in the postexilic community.

Using cross-cultural kinship studies, Steinberg (1993) reads Genesis 11:27-50:26 as a narrative on the descendants of Terah. In its present form, this material was used in post-exilic times to legitimate those who returned from the exile as the true Israel. They could lay claim to the land because they were the true descendants of the Terahite lineage (cf. Steinberg 1993:146).

Starting then with Genesis 11:27 ('This is the Toledot of Terah') Steinberg (1993:39) divides the material into three matriarchal cycles: Genesis $11: 10-25: 11,25: 12^{6}-35: 29$ and 36:1-50:26. Given that the status of the mother determines the direction of the genealogy, each cycle is named after the relevant woman. Genesis 11:10-25:11 is the Sarah-Hagar cycle, in which Abraham is resented for being married to two women. Marriage here takes the form of 'polycoity' (cf. Steinberg 1993:152). Genesis 25:12/19-35:29 forms the Rebecca cycle, depicting a monogamous marriage with Isaac. In Genesis 36:1-50:26, Jacob is married to more than one wife ('sororal polygyny' - cf. Steinberg 1993:152) and this is called the Leah-Rachel cycle.

In each of these cycles a similar plot is found. Each cycle starts with the words 'this is the Toledot of...' (ואלה תicho) and deals with the intrigue of progeny. The denouement depends upon the type of marriage made, the procreation of offspring and the question regarding the legitimate heir to the land. As soon as all of these problems are solved, the story advances to the next stage. Steinberg (1993:135), therefore, concludes that all of these cycles are arranged according to the same three interrelated concepts of 'heirship, marriage and ownership of land'.

We can use Steinberg's model to read the narrative of Dinah's rape (Gn 33:18-34:31). According to this model, the narrative is part of the Isaac-Rebecca cycle (Gn 25:12/19-35:29), which deals with the question of an heir to Isaac's name and property. The Dinah narrative should therefore be read in terms of that theme. Twins were born from Isaac's marriage with Rebecca (Gn $25: 19-26)$. The question is raised whether the first born, Esau, or the second son, Jacob, will be the heir to continue the bloodline. This conflict is resolved when Rebecca, through her conniving manipulations, sees to it that the younger, Jacob receives Isaac's blessing.

The story of Dinah (Gn 33-34) is painted against the background of these events. As a grown man, Jacob was on his way from Paddan Aram and camped within sight of the city of Shechem. There he bought a plot of ground from a certain Hamor (Gn 33:19). During this time Hamor's son, Shechem, violated Jacob's daughter, Dinah (Gn 34:1-2). Hamor was very fond of Dinah and asked his father to get her for his wife. In the ensuing negotiations between the two fathers, the brothers of Dinah set down deceitful conditions. They urged Hamor and his people

5.For a more detailed discussion of Steinberg's publication see Venter 2007b:12191225.

6.Genesis 25:19 also starts with the formula ואלה תith starting Isaac's Toledot and is the more probable starting point of the second cycle. to be circumcised first (Gn 34:13-17). Jacob's sons, Simeon and Levi, abused the situation by attacking the city and killing all of its male inhabitants while they were still in pain after the circumcision (Gn 34:25-29). When their father chided them for this, Simeon and Levi justified their deed as the penalty they dealt out for what the inhabitants did to their sister (Gn 34:3031).

The terms Steinberg used for her theory are all present in this narrative. We again have to deal with heirship, marriage, and ownership of land.

Concerning heirship, Jacob and his children are characterised as deceitful people who obtained their inheritance unlawfully. Jacob obtained Isaac's blessing by deceiving his father into believing that he (Jacob) was the first born, Esau (Gn 27:1-40). Leah's second and third sons, Simeon and Levi, also acted treacherously by not only breaking their contract with the inhabitants of Shechem, but also killing them when they were in an awkward position and unable to defend themselves (Gn 34:25-29). The narrative omits Dinah's reaction to the events and does not tackle the question of her possible pregnancy as a result of the rape (i.e. there are several gaps in the narrative) Thus, while the issue of procreation is not directly addressed here, the reader is lured into filling the gaps. The reader can only speculate why the brothers prevented the contract to be realised. Why were they unwilling to give their sister away in marriage to a Shechemite? Was it merely a matter of shame and the brothers taking revenge for what was done to their sister, or was there more to it?

The second issue in Steinberg's triad, that of marriage, plays a central role in the plot. The negotiation between the two fathers is done in the customary way of the ancient Near East. The plot can be summarised in the question: 'Will they reach an agreement and will this lead to matrimony?' Hamor's son, Shechem, offers to pay the bride price (mohar) whatever it is (Gn 34:11). Ironically, the price was more than he thought it would be. The denouement takes an unforeseen turn, costing him and his fellow Shechemites more than they could pay - their lives. Thus, the narrative seems to be about non-marriage - about preventing a marriage at all costs. If Hamor weds Dinah, an intermarriage will take place creating the possibility that Jacob's offspring may marry the daughters of the Shechemites and vice versa. This would lead to the cessation of pure Israelite identity and start a new mixed population. The condition set for the marriage is clear; the inhabitants of Shechem will first have to be circumcised 'to become like us' (אם תהיי כמנו Gn 34:15). Only after they have become 'Israelites' (one people והיינו לעֵם אחד Gn 34:16) would a marriage be possible. The issue then becomes how this type of marriage can be prevented. The story ends where this proposed marriage is successfully averted albeit in a very deceitful way.

The third term land also plays an important role. The Shechemites

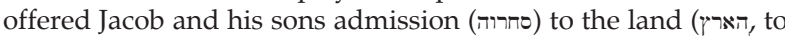
live (תשבו) alongside the inhabitants (אתנו), and even to acquire property in it (והאחזו בה) (Gn 34:10). This offer is partly repeated in Genesis 34:21. The family of Jacob could live together with the Shechemites in their land, and move freely in it, because there was more than sufficient space in which all of them could live. The right to acquire property in the land is not repeated when Hamor and his son try to persuade the inhabitants of Shechem to comply with the conditions set by Jacob and his sons. The initial purchase of a mere portion of the ground (חלקת השרדה) for a hundred pieces of silver at the beginning of the narrative is now extended to ownership of the land (שר דארץ). As with the rest of the cycle and those surrounding it, ownership of land is related to a marriage that is to be consummated.

In summary, progeny (in the sense of avoiding it when it comes to the marriage with wrong people), marriage (in the sense of avoiding it with non-Israelites) and possession of land (related 
to the consummation of a marriage) form the three cornerstones of the episode. Together, these three concepts deal with the unique identity of Jacob and his children. Although in negative terms, a triad of interrelated concepts is used here to spell out what the unique identity of Israel is.

\section{TRIADS IN EZRA-NEHEMIAH}

Intermarriage is also dealt with in the books of Ezra and Nehemiah. Both books use a constellation of interrelated concepts in their reform programs to motivate the community of faith to accept a new identity. Ezra uses a triad of law, land and matrimony to form a temple-centred community. Nehemiah relates law and land to a written agreement to live a life of dedication to God. ${ }^{7}$

\section{Ezra 9:6-15}

Land is the central issue in Ezra's penitential prayer in Ezra 9:6-15. He relates the occupation of the land to God's Law, by confessing that the land God gave them was the space in which these laws were to be enacted. Israel, however, transgressed the Lord's commandments in the very land that he gave them, as proved by the existence of unlawful marriages. Land and law are thus connected here to the issue of intermarriage. The triad of land, law and marriage thus forms the basis of his penitential confession and the ground for his plea for forgiveness.

Ezra 9:6-15 has a symmetric construction. ${ }^{8}$ In the centre (Ezr 9:10-12), marriage to heathen women is linked with the land that God gave them. In the surrounding frame (Ezr 9:8-9, 9:13-14), the idea of the remnant is expressed. In spite of their continuous transgression of marrying such women, God allowed a remnant to return to their land from the exile. Remnant and land are thus closely linked here. This, in turn, is framed by an outer circle in 9:6-7 and 9:15 where guilt is confessed in terms of God's Law and their transgressions of the law by marrying forbidden women.

Ezra's confession of guilt is, therefore, a theological construct in terms of the three interrelated concepts mentioned above: land law and matrimony. Being, in essence, a confession of faith, it aims at underlining God's mercy and his grace for still loving his people in spite of everything they did. God's commandments could have been formulated in many different ways. The author, however, linked them directly to the issue of the land God gave the Israelites and the practical opportunity they had to live in it according to his law. He chooses a concept that not only has theological contents but is also very practical in its ethical dimensions. Moreover, the author chooses an ethical matter as his third component. Israel's refusal to obey the law is linked to, amongst all other possibilities, inter marriage with women who are not from Israelite stock. This triad ${ }^{9}$ of interrelated terms is then used explicitly as a theological construct to confess human sins, and implicitly to confess the majesty of God. Theology and ethics are thus closely knit here.

\section{Nehemiah 7:72b-10:40}

This unit consists of three episodes ${ }^{10}$ : the reading of the Book of the Law and the Succoth festivities (Neh 7:72b-8:18), Israel's

7.This dedicated life includes several aspects such as purity, holding the prescribed holy festivals, consummating correct marriages and providing service facilities at the temple. cf. Nehemiah 10:129-138.

8.Cf. Venter 2005:549-554

9.Bossman (1979:36) talks of four principal value concepts (Israel, Torah, God's righteousness and his mercy) that 'interact in a harmonious relationship, forming the warp and woof of Ezra's midrashic rhetoric'. This construct is the manifesto for Ezr's reform program during the second temple period. He propagates a unique Ezra's reform program during the second temple period. He propagates a unique identity formulated in terms of obedience to the Torah mainly performed in cultic service and avoidance of marrying to outsiders. Bossman therefore works with a part construct. In essence, however, he also uses a construct of interrelated concepts to indicate Ezra's theology and his reform program.

10.For a more detailed discussion see Venter, 1995:720-731 and Venter 2005:561. confession in the form of a historical review and a penitential prayer (Neh 9:1-37) and the people's agreement to follow God's Law (Neh 9:38-10:40). To compose this unit, the author(s) used, inter alia, polylogic (form critical and social) exegesis and an extended form of aggadic exegesis concerned with the religious ethos of Israel. Aggadic exegesis usually deals with theological, reflective, moral, and practical matters.

In the two rallies narrated in Nehemiah 7:73b-8:12 and Nehemiah 8:13-18, the reading of the Torah plays a central role. In the following episode (Neh 9:1-37), the events are narrated by using the form of two Gattungen, (1) Historical Review and (2) Penitential Prayer. The Historical Review in 9:5b-31 follows the traditional formula of sin-punishment-repentance-remission, and is echoed in 9:32-35 in which the sin of the present generation is confessed. The dirge in 9:36-37 uses the theme of the land ${ }^{11}$ to depict the irony that the Judeans became slaves in their own land. In the final episode (Neh 9:38-10:40), the community signs an agreement to live in dedication to God by keeping themselves pure, commemorating the holy festivals, preventing unlawful marriages, and sustaining the service at the temple.

In this 'imposing attempt to create a model of a "true Israel" during the mid-Persian Period (ca 450 BC)' (Oeming 2006:582), a reform movement aims at providing the community with a new identity in line with the Torah. Cultural transformation takes place in terms of law, land and cult. A new community of faith is to be formed around law, the repossession of the land, and a dedicated life. Again three interrelated concepts (Torah, land and cult) are used in a triad to formulate the program of renewal.

\section{Ezra-Nehemiah}

A triad consisting of the concepts of law, land and purity (correct marriages, cult, holy feasts etc.) forms the basis of both of these penitential prayers. ${ }^{12}$ Of course, there are differences between Ezra and Nehemiah. In Ezra's case, his priestly temple-orientated theology sees the identity of the community particularly in terms of matrimony. Although Nehemiah also includes marriage in his programme, he makes it only part of a national-orientated 'Jewish identity within an accepted imperial framework' (Willamson 1999:282). Temple, cult personnel and religious custom are points of cohesion forming an overall programme of transformation. Both use Deuteronomy 7:1-4 as basic text for reflecting on foreign marriages, but this is accommodated in two different theological constructs. Basically, however, both use a triad of nearly similar interrelated concepts as their theological model.

\section{THE CAIRO DAMASCUS DOCUMENT}

The Damascus Document represents one peculiar form of Judaism during the 3 rd century to 2 nd century BCE. It is more or less contemporaneous with the tradition of the Book of Jubilees and also uses marriage as one of its theological-ethical concepts. ${ }^{13}$ This collection of texts comes from Qumran and represents a form of Zadokite Judaism from the 3rd century to 2 nd century BCE. An interpretation of the marriage laws of Moses is presented in Subsection 2 of this document (CD $\mathrm{V}: 1-\mathrm{V}: 2-6)$. Here the author(s) used several biblical quotations and midrashim to prove to those outside the community that their interpretation of the Mosaic law is wrong.

11.Newmann (1999:99-100) pointed out that there is no mention of deportation or life outside the land here. Her theory is that the mitigation of the Exile implicating the loss of the land should be understood in terms of the author's desire to establish an inalienable claim to the land. The concept of land plays a central role in the author's theology.

12.According to Zlotnick-Zivan (2000:3), the three interrelated themes used in EzraNehemiah are 'the "reading of a sacred text, public spectacles, and the vilification Nehemiah are the "reading of a sacred text, public spectacles, and the vilification vilifed is the foreign wher and the land is replaced by his ido of public spectacles (meetings).

13.See Venter 2003b:598-622 for a discussion of this document. 
Reference is made to Genesis 7:9 in CD V:1a to prove that the marriage laws of God were already given to Noah. It was already written down in the book of the law Noah took with him in the ark. The principle of monogamy was revealed in God's command to take animals two by two into the ark. The document refers to opposing groups who transgressed the marriage laws of God. During their lifetime they married more than one woman and therefore became guilty of fornication. They also married blood relatives and transgressed Moses' explicit prohibition in this regard. In this process they defiled the sanctuary.

In CD V:2-6 the incident is recalled when David committed adultery with Bathsheba. He transgressed the command that the leader should not multiply wives (cf. Deut 17:17) and therefore broke the rules of monogamy in God's book of the law which Noah already had with him. As the law was only revealed later to the members of the Zadok group, David lived in the 'dark ages' when the law was sealed and he could, therefore, be pardoned for what he did.

These two texts of CD V:1a and CD V:2-6 indicate that priestly marriages were a point of dispute in the author's time. According to the view of this group, bigamy and marriages to blood relatives form the contents of fornication. They defile the sanctuary. Once again, a triad is found here: the law (already given at creation) is interrelated to the sanctuary/ priests and to the issue of (monogamous) marriage.

\section{THE BOOK OF JUBILEES}

The Book of Jubilees, from the 2nd century BCE, also addresses the problem of marriage in 30:1-25 and 41:1-28. It is particularly interested in halakah, defined as 'a "way" of life spelled out in teachings, ordinances and practices derived from the interpretation of biblical laws' (Nickelsburg 2005:68) and so rewrites Genesis 1 - Exodus 12 by incorporating legal material into the biblical narratives to provide ethical guidelines to the author's compatriots. A theological triadic construct is also found in Jubilees' rendition of the Dinah events.

\section{Jubilees 8-9}

The Table of Nations in Genesis 10 served as the arch text for Jubilees 8-9. The depiction of Israel's identity given in Genesis in genealogical terms is changed here into one using spatial terms. ${ }^{14}$ The author used a triad of space, time and identity to advance his personal conviction of who really belongs to Israel.

In Jubilees 8:11-9:15, the author of Jubilees combined spatial conceptualisations with his particular chronological scheme of jubilee units to rephrase the list of Noah's descendants in Genesis 10:1-32. The תולדת heading of Genesis 10:1 introduces the contents of the rest of Genesis. This term is again used as the caption of each of the following three cycles as indicated in Section 2 above. In Genesis, group identity is conceptualised in terms of genealogy, while marriage and living in the land are variable themes refining the meaning of kinship. In Jubilees 8-9's rendering of Genesis the term gives way to 'land' as the main concept. Jubilees uses space and time instead of genealogy to portray the identity of the true Israel. Relationship is now conceptualised in terms of sharing the same space, the holy territory with its eternally fixed borders that God allotted to Israel. In two interrelated parts (Jub 8:10-30, 9:1-15), the author used an existing Noah tradition and several boundary texts from the Old Testament to construct an ideology about Israel's real identity in terms of space, time and society. Demarcated space along with realised eschatological time defines Jubilees' view of Israel's true identity. During the final jubilee, the author's compatriots will find their identity in terms of Jerusalem and the holy land God originally allotted to them.

\section{Jubilees 23}

The author of Jubilees used a large array of techniques for rewriting the books of Genesis and Exodus. In the layered text of Jubilees 23:8-32, the author linked Abraham's age at his death to a heptadic scheme of jubilees. He then used Psalm 90:10 to rectify this scheme and accommodate the role of sin in history. He indicates a pattern of declining and inclining human longevity. On this pattern he superimposed a Deuteronomistic retributive scheme of sin and salvation and fitted this combination into an apocalyptic framework. ${ }^{15} \mathrm{He}$ presented this to his contemporaries as indication of the turning point in history that occurred in Abraham's time, which was brought about for those who searched the law and returned to the way of righteousness (cf. Jub 23:26).

A triadic scheme can also be indicated here. The following terms all deal with time: longevity, history as a cycle of sinpunishment-repentance-salvation, a heptadic jubilees scheme, eschatological expectation. This concept of time is related to the issue of the law, that is, those who 'have forgotten the commandments and covenant and festivals and months and Sabbaths and jubilees and all of the judgments' (Jub 23:19), in opposition to those who search the law (Jub 23:26) and both of these (time and law) automatically link to the identity of the true Israel as people being obedient to the law. The triad therefore comprises the three cornerstones of time, law and identity.

\section{Jubilees 30:1-25}

Using the above summary of triadic schemes we can now turn to Jubilees 30:1-25. This rendition gives a new meaning to the story of Dinah's rape in Genesis 33:18-34:31. The question, however, is whether a triadic scheme is used here as well. If this is the case, then the next question will be how does its triad compare to the one used in Genesis?

The author used an array of several intertextual techniques to rewrite the original narrative: implicit and explicit allusions, omitting material, adding illocutive additions, making dialogic comparisons et cetera.

In Jubilees' rendition, Dinah did not go out to visit the women of the region, but was rather carried off into the house of Shechem, the son of Hamor, who defiled her (Jub 30:2). ${ }^{16}$ Nothing is repeated here from Genesis concerning Shechems' love for Dinah, his request to marry her, the negotiations between the fathers, the offer that the Israelites could live in the land and buy property there, or the condition that the Shechemites are to become circumcised first. The Shechemites are de-characterised and written out of the story. Any hint of sympathy for Shechem and his people is thus removed.

While the Genesis narrative depicts the Shechemites as defenceless because of the circumcision they underwent, the Jubilees story merely states that

Simeon and Levi came unexpectedly to Shechem and executed judgment on all the men of Shechem, and slew all the men whom they found in it, and left not a single one remaining in it.

(Jub 30:4). ${ }^{17}$

In Genesis, Simeon and Levi recklessly killed Hamor and his son Shechem with the sword, and took Dinah out of Shechem's house. The other sons of Jacob came upon the slain, plundered the city, took their animals and whatever was in the city and in the fields, all their wealth, all their little ones and their wives,

15. This theory is set out in Venter 2007a:463-480.

16. This change to a passive role for Dinah stands in stark contrast to the depiction of women in Jubilees where they 'are more fully developed ... made more integral to women in Jubilees where they are more fully developed ... made more integral to history of Israel as God's selected seed' (Halpern Amaru 1994:609). It is probably linked to the removal of the actions of the Shechemites here. 
and all that was in their houses (cf. Gn 34:26-29). In Jubilees, it was the other brothers who brought Dinah out of the house of Shechem, took captive everything that was in Shechem: their animals, all their wealth and all their flocks, and brought them all to Jacob, their father (cf. Jub 30:24). In both Genesis and Jubilees, Simeon and Levi took the honour. In both narratives the role of the brothers is that of being plunderers. In Genesis, however, they are more than mere despoilers and are depicted as the superheroes.

While Genesis does not evaluate the deeds of the brothers directly, in Jubilees 'it was reckoned unto them for righteousness, and it is written down to them for righteousness' (Jub 30:17). The Shechemites were delivered into the hands of the two sons of Jacob. The Lord delivered them so that the sons of Jacob might exterminate them with the sword and execute judgment upon them (30:16). This righteousness is even attributed to their brothers! Thus, on

the day when the sons of Jacob slew Shechem a writing was recorded in their favour in heaven that they had executed righteousness and uprightness and vengeance on the sinners, and it was written for a blessing.

In Jubilees this event is used to boost the Levitical priesthood. Levi fulfilled righteousness on this occasion and throughout his life. He 'was zealous to execute righteousness and judgment and vengeance on all those who arose against Israel and he hath been recorded on the heavenly tables as a friend and a righteous man' (Jub 30:20). This righteousness will come to him and to his descendants after him $(30: 18)$. As result of his deeds, 'the seed of Levi was chosen for the priesthood, and to be Levites, that they might minister before the Lord continually, and that Levi and his sons may be blessed for ever' (Jub 30:18).

Another change made is found in the final scene of the episode. In Genesis, Jacob reprimands Simeon and Levi for what they did. They made Jacob odious to the inhabitants of the land, the Canaanites and the Perizzites. They outnumber his household. In case of an attack they will destroy him (Gn 34:30). In Jubilees he rebukes all of his sons. His reproach is based here upon his fear of the Canaanites and the Perizzites (Jub 30:25). The fear is not extended upon. Genesis ends with an exculpating remark by the two brothers: 'Should our sister be treated like a whore?' (Gn 34:26). Jubilees, however, ends on a victorious note: 'the dread of the Lord was upon all the cities which are around about Shechem, and they did not rise to pursue after the sons of Jacob; for terror had fallen upon them' (Jub 30:26).

The most obvious change in Jubilees is the linking of this episode to the law given to Moses. A comparison of the contents of the two chapters shows that not only the subject of the law given to Moses is added in Jubilees, but also that 16 out of the total of 26 verses are dedicated to this topic (cf. Table 1: The Law of Moses).

Another 'shift' can be seen in the omission of circumcision ${ }^{18}$ and the role of the Shechemites. The focus shifts here towards the brothers, and especially Simeon and Levi. They are the ones who 'executed righteousness and uprightness' (Jub 30:23).

Next to revealed law and the righteous identity of the brothers, the third concept used is that of exogamy. While Genesis 34 does not qualify as a prooftext for a ban on intermarriage, Jubilees does exactly that by making certain crucial omissions (cf. Werman 1997:6). The author uses the incident of the rape of Dinah as an illustration and application of the law against intermarriage and as indication of the true identity of his fellow Jews. This chapter is intended to give an example of the unhappy results when Jews marry outside their race. This is a motif found throughout the book in its teaching of the direct relation between marriage and purity/impurity (cf. Jub 20:4, 22:20-22, 25:3-10, 27:8-10, 40:1-13,

18.This is probably the way the author addressed the problem of the moral issue that the Jacobites made a covenant of circumcision with the Shechemites but kill them afterwards - by simply leaving it out of his story.
TABLE 1

The Law of Moses

\begin{tabular}{ll}
\hline Jubilees & Genesis \\
\hline Dinah ravished (Jub 30:1-3) & $\begin{array}{l}\text { Dinah's rape (Gn 34:1-4) } \\
\text { Negotiations and circumcision } \\
\text { (Gn 34:5-24) }\end{array}$ \\
& $\begin{array}{l}\text { Simeon and Levi killed the men of } \\
\text { Simeon and Levi executed judgment on the } \\
\text { men of Shechem (Jub 30:4-6) }\end{array}$ \\
$\begin{array}{ll}\text { Decree to Moses not to marry Gentiles (Jub } \\
\text { 30:7-22) }\end{array}$ & \\
Sons of Jacob slew Shechem (Jub 30:23-24) & $\begin{array}{l}\text { Brothers plunder Shechem (Gn } \\
34: 27-29)\end{array}$ \\
Jacob reproached the brothers (Jub 30:25-26) & $\begin{array}{l}\text { Jacob reprimands Simeon and } \\
\text { Levi (Gn 34:30-31) }\end{array}$ \\
\hline
\end{tabular}

This section on exogamy (Jub 30:7-22) introduces several subthemes (cf. Table 2: Exogamy).

\begin{tabular}{ll} 
& \multicolumn{1}{c}{$\begin{array}{c}\text { TABLE 2 } \\
\text { Exogamy }\end{array}$} \\
\hline Jubilees 30:7-12 & $\begin{array}{l}\text { A transgression with no atonement: giving your } \\
\text { daughter to a Gentile (cf. Exogamy) }\end{array}$ \\
Jubilees 30:13-16 & $\begin{array}{l}\text { Intermarriage means defilement (cf. Defilement) } \\
\text { Levi as administrator of righteousness (cf. Levi) } \\
\text { Jubilees 30:17-20 }\end{array}$ \\
Jubilees 30:21-22 & $\begin{array}{l}\text { Be friends of the Lord and do not transgress his } \\
\text { commandments (cf. Identity) }\end{array}$ \\
\hline
\end{tabular}

41:1-28). The narrator therefore changed the original story into a powerful attack on exogamy. The focus is shifted from the shame of Dinah's rape to the shame of intermarriage between different groups. This prohibition was ordained and written in the heavenly tablets given to Moses (cf. 30:9) that no one of Israel is allowed to marry someone not from Israel. The author links up with the Moses tradition and sees the prohibition on intermarriages as part of the laws revealed to Moses at the mountain (an often used technique in Jubilees of reverting later events to earlier events).

\section{Exogamy}

The list of the wives of Jacob's sons in Jubilees 34:20-21 contains several names from Canaanite, Aramaic, Mesopotamian and Egyptian origin. There is no direct condemnation here of these marriages with non-Israelite women. ${ }^{19}$ Jubilees 34:21 only states that Simeon, who was married to 'Adîbâ'a, a Canaanite woman, 'repented' and 'took a second wife from Mesopotamia as his brothers'. Repentance is linked here with marrying a woman from a different nationality. In Jubilees 41 , the union between Er and his daughter-in-law Tamar is condemned, not because it was a mixed marriage, but because it was a consummation between a father-in-law and a daughter-in-law that is forbidden in Leviticus 18. The conclusion drawn from this incident by Jubilees (cf. Jub 41:25) is that any transgression of the laws on forbidden sexual relations ${ }^{20}$ brings about 'uncleanness and pollution'. The transgressors are to be burned by fire (Jub 41:25, 26) - a punishment that was originally meted out only for the daughter of a priest who defiled herself by prostitution (cf. Lv 21:9), but now extended to every woman in Israel who marries a gentile (Jub 30:7). A set of higher and more rigid rules for religious purity is propagated here linked to the prohibition on intermarriage.

In Abraham's last words to his children and grandchildren (Jub 20:1-11) he warns them against taking wives 'from the daughters of Canaan' (20:4). This "subtle" critique of exogamy by highlighting problematic unions' (Coblentz Bautch 2007)

19.Cana Werman (1997) states that Jubilees tries to remove intermarriage accounts involving patriarchs. Aramean women are made more acceptable as well Egyptian women for we

20.William Loader, in his work, Enoch, Levi, and Jubilees on sexuality: Attitudes towards sexuality in the early Enoch literature, the Aramaic Levi document, and the wards sexuality in the early Enoch literature, the Aramaic Levi document, and the
Book of Jubilees (2007), also deals with this matter, but has not been consulted for this paper 
is repeated in Rebecca's admonishment to her son Jacob not to marry a Canaanite woman (Jub 25:1-3). An explicit denouncement of intermarriage is given in the account of the rape of Dinah in Jubilees 30:1-26. According to Macaskill (2007), Ezra's concept of the holy seed is taken up here and developed into an explicit ban on intermarriage. What probably underlies this development is the intertextual reading of Exodus 19:5-6 ('kingdom of priests and holy nation') and the extension of the laws in Leviticus 21:9 as indicated above. In the Genesis narrative, the 'disgraceful thing' (Gn 34:7) that happened and Jacob's negative attitude to the Canaanite Shechem's attempt to marry his daughter Dinah (Gen 34:8-9) can be related to the figurative rule in Deuteronomy 22:10 against ploughing with an ox and an ass together.

Shechem, the son of the Ass, Hamor, 'ploughed' Dinah, the daughter of the Ox, that is, the House of Jacob. Jacob so refers to his house in Gen 49:6 when he refers back to the incident in Genesis 34

(Carmichael 2007)

The Genesis narrative seems to be on the side of Simeon and Levi, who fiercely opposed the idea of intermarriage between the house of Jacob and any Canaanite group.

The concept of marriage still operates in Jubilees. It is, however, used in a negative sense. It now becomes an issue of avoiding specific types of marriages. In Jubilees 22:11-23, Abraham is depicted as the defender of the 'sacred seed'. He condemns all exogamic marriages on the basis of the sin of Ham (Jub 22:20-21). In the Dinah narrative, the author of Jubilees narrates Jacob as aligning himself with Simeon and Levi in their anger at Shechem's seduction of Dinah (Jub 30:3, 4). They consider sexual violence as an offence against the clan of Jacob. Consequently, the narrator in Jubilees omits all those elements 'which could allow for a more accommodating reading or interpretation' (Arcari 2007). Jubilee omits the previous relationships between Jacob and the Shechemites, Hamor and Jacob's discussion of intermarriage and the proposal of circumcision as a condition, even 'the prospect of conversion-not simply intermarriagein fact, is off limits for Jubilees' (Coblenz Bautsh 2007). Simon and Levi are portrayed as heroes, meting out punishment on the Shechemites that had been divinely preordained. They are lauded for killing the inhabitants of Shechem and sacking their city. This gruesome act is justified by the angel of the presence who makes clear that no Israelite is to give his daughter or sister to a foreigner, nor is he to marry a foreign women (cf. Jub 30:7, $11)$.

The ideological justification for the prohibition of the exogamic unions appears to be the most important part of the narration.

[S]tarting from Ex 19:5-6, Jubilees extends the priestly purity to Israel as a whole; juxtaposing this text with Lev 21:13-15 and Lev 18:21. Lev 21:13-15 deals with the illicit unions of the daughters of priests; in Lev 18:21 with the sacrifices offered to Moloch by Hebrew and Canaanite peoples.

(Arcari 2007)

Jubilees can be understood to say that sexual union with a Gentile is prohibited by Torah law (Lv 18, 20). It 'results in defilement (Gen 34) and profanation (Lev 21) of a variety of sancta-particularly the holy seed of Israel (Ex 19, Lev 18 and 20, and Ezra) —not just priests, but all Israelites, since all Israel is holy (Ex 19, Dt 7:6, and Ezra)' (Macaskil 2007).

\section{Defilement}

The Book of Jubilees often has recourse to the concepts of purity and impurity. Although the book is very much concerned with purity, ritual purity is addressed only in a few of its passages (cf. Klawans 2000:47). Moral impurity, on the other hand, is one of Jubilees' main concerns. Hayes (1999) called this type of impurity 'genealogical impurity'. He claims it to be different because its real effect comes about in the offspring, through the 'spoiling' of the purity of lineage. According to Hayes (1999), the underlying rationale for a ban on interethnic sexual unions is not the fear of contracting ritual impurity from a Gentile, but rather the fear of profaning the holy seed of Israel - an entirely distinct concern unconnected with an alleged principle of Gentile ritual impurity.

(Hayes 1999:5)

The book insists upon the genealogical purity of the sacred line. Both parents are required to be of pure lineage.

Moral impurity is caused mainly by idolatry, bloodshed, and sexual sins. Gentiles behave in morally abhorrent ways by committing sexual sins and worshipping idols. To stay pure, Israel is to separate themselves from them. Intermarriage, therefore, is a central concern in Jubilees (cf. Jub 20:4, 22:2022, 30:7-17). Intermarriage with gentiles defiles not only the individual, but also the whole nation, the divine Name and the sanctuary (Jub 30:10, 15-16). It is a transgression for which no atonement is possible (Jub 30:13-16).

Jubilees, however, is not fully consistent on this matter. It turned Jubilees 30 into a 'paradigmatic example for the law prohibiting intermarriage with Gentiles' (Werman 1997:9). Joseph's marriage to an Egyptian woman, however, is not problematic (Jub 40:10) and neither are Simeon's and Judah's marriages to Canaanite women. Endogamous unions are favoured for the patriarchs and matriarchs, but as Werman (1997:3) has pointed out, Jubilees tolerates these marriages if they are to lower status wives of other backgrounds, not being of Canaanite origin. It seems that Jubilees is more tolerant of marriage to Egyptians than to other Gentiles in general. Marrying any Canaanite, however, is forbidden.

The paradigmatic story of Dinah in Jubilees 30 offers a clear statement of the author's point of view regarding exogamy. The key words here are 'fornication' and 'impurity'. Shechem, and therefore also the Shechemites, 'defiled' Dinah (Jub 30:2$3,5-6)$. They did not only treat Dinah like a whore but they ultimately defiled Israel (Jub 30:8-9), creating an impurity from which 'Israel will not become clean' (Jub 30:14). Following the line of Leviticus 20 in demanding punishment for offenders, and in accord with Leviticus 18, the author assesses the deed of marrying a daughter to a foreigner as an act that defiles the nation (cf. Werman 1997:14). Shechem's act could have defiled the nation and it was therefore appropriate that Simeon and Levi killed the entire city (cf. Werman 1997:16). They had to eradicate the perpetrators. The author therefore transformed the scriptural chapter from a condemnation of Simeon and Levi for their violence into a commendation and even a warrant for Levi's elevation to the priesthood.

\section{Levi}

When the book of Jubilees does deal with the issue of ritual purity,

it always entails a 'reference to a sanctuary', be it past, future or temporal: the Garden of Eden ...; the future Temple ..., which is the place where priests will observe purity in handling sacrifices ...; and perhaps the Sabbath as a 'sanctuary in time'.

(Doering 2007)

Bethel, especially, is called 'the house of the Lord', 'the house of God', 'and the gate of heaven' (Jub 27:25). It is here at Bethel that Levi dreamed that he was ordained and made the priest of God (Jub 32:1). At the same place his father Jacob 'clothed him in the garments of the priesthood' (Jub 32:3-9).

The Book of Jubilees depicts Levi as the guardian and teacher of the law. A clear instance can be found in 30:12 (the rape of Dinah). Here the angel of the presence says to Moses: '[f]or this reason I have written for you in the words of the law all the deeds of the Shechemites which they wrought against Dinah'. The angel claims here to have written something in the law and uses this incident to direct the readers to the law to understand the meaning of the event. Where Genesis has no ordination 
scene of Levi and condemns Levi and Simeon for their violent act (cf. Gn 34:30, 49:5-7), Jubilees uses this story as 'a warrant for Levi's elevation to priesthood' (VanderKam 2008:421) because of his zeal and violence in acting to prevent the marriage of his sister Dinah to the Canaanite Shechem (Jub 30:18-20). According to Jubilees he was a righteous man. Levi acted here as righteous priest executing the law to preserve purity in Israel. What is interesting here is that it is not ritual purity he conducted (as in Jub 32, where he received and sacrificed tithes) but rather moral purity preventing the uncircumcised Shechem to marry his sister. Impurity, in this case, comes from marriages to Gentiles. Marriage to a non-Israelite is described in this episode as having the potential to pollute the sanctuary. Whoever marries a Gentile will receive 'plague upon plague, and curse upon curse, and every judgment and plague and curse will come upon him' (30:15-16) because he defiled the sanctuary of the Lord and profaned his holy name.

Different terms are associated here with one another: the priest (Levi) operating from the sanctuary applies the law that aims at preserving purity by prohibiting any form of intermarriage with a Gentile.

\section{Identity}

The main focus of the book of Jubilees 'is on Israel itself, and especially the question of its identity' (Oegema 2007). This can be seen in the way the book has been structured. The bulk of the book is about Abraham, Jacob, and their families. Chapters 11-45, that is 35 out of the total of 50 chapters, deal with Abraham and his descendants. Of these 13 chapters (Jub 11-23) are dedicated to Abraham and 22 chapters (Jub 24-46) to Jacob and his family.

The book emphasises the holiness of the Jewish nation as a whole. This holy identity is shown by being critical of Jews who transgress the laws pertaining to the calendar, circumcision and nudity and perhaps also the Sabbath (cf. Regev 2007). Holiness is especially depicted by contrasting the Israelites to the immoral gentiles. Contact with gentiles is condemned. In the case of 30:16, Jubilees even seeks to prevent someone whose daughter married a gentile from entering the Temple. The book discusses Genesis 34 in detail and uses it as a 'proof text' to forbid intermarriage (cf. Oegema 2007). Intermarriage was strictly forbidden because it threatens Israel's unique identity.

\section{CONCLUSION}

In the cases discussed above, theological constructs are presented in the form of triads. The narrative of Dinah's sexual assault deals with Israel's identity. In the context of the Toledot of Genesis where the triad of heirship, marriage and land plays the central role, the story deals with discouraged progeny, counteracting the consummation of marriage with Canaanites at all costs and occupation of land. Although the true offspring of Abraham are fraudulent and fallacious, the threat of defiling the bloodline is averted by taking drastic measures against the inhabitants of Shechem. The identity of Israel is depicted with a triad of terms of which two are used in a negative form: no offspring and no intermarriage with Canaanites.

Basically the same technique is used in the book of Jubilees. A construct of several interrelated terms is used not only in sections such as Jubilees $8-9$ and 23, but also in 30:1-25. The revealed law given to Moses on the mountain is explicated in the narrative of Dinah's rape. The Genesis story is changed into a powerful attack on exogamy. ${ }^{21}$ Israel's real identity is to be found in the example of Simeon and especially Levi who now become the heroes of the story. They and the brothers are the administrators of righteousness having prevented exogamy taking place. Moral purity must be sustained by totally avoiding

21.Werman (1997:2-3) reads Jubilees 30 as an answer to the problem of conversion during the end of the 2 nd century BC. The contemporary question can be asked: Is intermarriage possible in the case of conversion? any marriage between a Jew and any other nation. Defilement and righteousness are directly linked to marriage as the keystone of obedience to the law. Also, in this case, a triad is used: law, identity, marriage.

Compared to the narrative in Genesis, the issues of land and heirship are no longer of central concern. The law and identity of the Jewish community, now linked more to matrimony than ever before, form the triadic construct presented to the author's contemporaries. The triadic technique is maintained, although the central concepts have been changed to address the issues of the time.

\section{REFERENCES}

Arcari, L., 2007, 'The myth of the Watchers and the problem of intermarriage in Jubilees', electronic draft paper prepared for the 4th Enoch Seminar, Camaldoli, Italy, July 08-12, 2007.

Bossmann, D., 1979, 'Ezra's marriage reform: Israel redefined', Biblical Theology Bulletin 9, 32-38.

Carmichael, C., 2007, 'Law and narrative in Jubilees: The biblical precedent', electronic draft paper prepared for the 4 th Enoch Seminar, Camaldoli, Italy, July 08-12, 2007.

Charles, R.H., 2003, The Book of Jubilees or the Little Genesis, Book Tree, San Diego.

Coblentz Bautch, K., 2007, 'The depiction of women in the book of Jubilees', electronic draft paper prepared for the 4th Enoch Seminar, Camaldoli, Italy, July 08-12, 2007.

Doering, L., 2007, 'Purity and impurity in the Book of Jubilees', electronic draft paper prepared for the 4th Enoch Seminar, Camaldoli, Italy, July 08-12, 2007.

Halpern Amaru, B., 1994, 'The first woman, wives, and mothers in Jubilees', Journal of Biblical Literature 113/114, 609-626.

Hayes, C., 1999, 'Intermarriage and impurity in ancient Jewish sources', Harvard Theological Review 92, 3-36.

Janzen, W., 1994, Old Testament ethics. A paradigmatic approach, John Knox Press, Louisville.

Klawans, J., 2000, Impurity and sin in ancient Judaism, Oxford University Press, New York.

Macaskill, G., 2007, 'Priestly purity, Mosaic Torah and the emergence of Enochic Judaism', electronic draft paper prepared for the 4th Enoch Seminar, Camaldoli, Italy, July 08-12, 2007.

Mills, M.E., 2001, Biblical morality. Moral perspectives in Old Testament narratives, Aldershot, Ashgate.

Newman, J.H., 1999, Praying by the Book: The scripturalization of prayer in Second Temple Judaism. SBL Early Judaism and its literature 14, Scholars Press, Atlanta.

Nickelsburg, G.W.E., 2005, Jewish literature between the Bible and the Mishnah, Fortress Press, Minneapolis.

Oegema, G.S., 2007, 'Israel and the nations in the Book of Jubilees', electronic draft paper prepared for the 4th Enoch Seminar, Camaldoli, Italy, July 08-12, 2007.

Oeming, M., 2006, 'See, we are serving today (Neh 9:36): Nehemiah 9 as a theological interpretation of the Persian period', in O. Lipschits \& M. Oeming (eds.), Judah and the Judeans in the Persian Period, pp. 571-588, Eisenbrauns, Winona Lake.

Regev, E., 2007, 'Jubilees, Qumran and the Essenes', electronic draft paper prepared for the 4th Enoch Seminar, Camaldoli, Italy, July 08-12, 2007.

Steinberg, N., 1993, Kinship and marriage in Genesis: A Household economics perspective, Fortress Press, Minneapolis.

VanderKam, J.C., 2008, 'Recent scholarship on the Book of Jubilees', Currents in Biblical Research 6(3), 405431.

Venter, P.M., 1995, 'Die aard van die geloofsgemeenskap in Nehemia 9 [The nature of faith in Nehemia 9]', HTS Teologiese Studies/Theological Studies 51(3), 720-731.

Venter, P.M., 2003a, 'Intertekstuele aanduidings van die wêreld van die boek Jubileë [Intertextual references to the world of the Book of Jubilees]', HTS Teologiese Studies/Theological Studies 59(3), 957-989. 
Venter, P.M., 2003b, 'Historical review in the Damascus Document', Verbum et Ecclesia 24 (2), 598-622.

Venter, P.M., 2005, 'Die skuldgebed in Esra 9:6-15 [The Penitential Prayer in Ezra 9:6-15]', HTS Teologiese Studies/Theological Studies 61(1\&2), 545-563.

Venter, P.M., 2007a, 'Intertextuality in Jubilees 23', HTS Teologiese Studies/Theological Studies 63(2), 463-480.

Venter, P.M., 2007b, 'Die huwelik as identiteitsmerker in die $\mathrm{Ou}$ Testament [Marriage as identity marker in the Old Testament]', HTS Teologiese Studies/Theological Studies 63 (3), 1213-1237.

Venter, P.M., 2008, 'Space, time and group identity in Jubilees 8-9', HTS Teologiese Studies/Theological Studies 64(1), 631650.
Werman, C., 1997, 'Jubilees 30: Building a paradigm for the ban on intermarriage', Harvard Theological Review 0/1, $1-22$.

Williamson, H.G.M., 1999, 'The belief system of the Book of Nehemiah', in B. Becking \& M.C.A. Korple (eds.), The crisis of Israelite religion: Transformation of religious tradition in exilic and post-exilic times, pp. 276-287, Brill, Leiden.

Wright, C.J.H., 1983, Living as the people of God: The relevance of Old Testament ethics, Inter-Varsity, Leicester.

Wright, C.J.H., 2004, Old Testament ethics for the people of God, InterVarsity, Downers Grove.

Zlotnick-Sivan, H., 2000, 'The silent women of Yehud', Journal of Jewish Studies 51(1), 3-18. 